\title{
SECURITY SITUATION IN SECONDARY SCHOOLS IN TUZLA CANTON
}

UDC 373.3:351.75(497.6 Tuzlanski kanton)(049.5)

\author{
Dževad Mahmutović ${ }^{1}$ \\ Ranko Kovačević \\ Bisera Kalaba \\ Institute for Human Rehabilitation, Tuzla \\ Faculty for education and rehabilitation University of Tuzla \\ Faculty of Law University of Tuzla
}

Received: 03.03.2011

Accepted:12.07.2011

\begin{abstract}
In this research has been presented an assessment of safety situation in schools, examined through the attitudes of students and teachers of secondary schools in five municipalities of Tuzla Canton. The sample consisted of 160 subjects, who for the purposes of this research divided in three subsample: male students, female students and professors. The research was conducted as a questionnaire, where on the posted statements subjects chose one of five responses on the Likert-type scale. The results of the research showed that subjects generally have unfavorable attitudes about security situation in secondary schools, which makes them feel very insecure. By descriptive analysis, besides these attitudes, it was determined that there are certain differences between the subsamples per individual variables. By analysis of variance, about influence of different status (student-professor) on the subsamples attitudes about safety in schools, it was determined that these differences were not statistically significant at the level $p<.05$ in results for the three subsample $(F=.421, p=.245)$. In relation on manifested negative attitudes about safety in schools, but also the homogeneity of results, in relation on the total sample of subjects, it is necessary to determine an adequate strategy of action, develop appropriate programs for work with students and make their prompt implementation in order to achieve safer living conditions and work in the school environment.
\end{abstract}

Key words: security, students, teachers, schools.

1 Correspodence to:

Dževad Mahmutović, MSc, Institut for Human Rehabilitation, Tuzla

Aleja A. Izetbegovića 20, 75 000, Tuzla (Bosnia and Herzegovina)

Phone: +38761804 941

E-mail: mahmutovicdzevad@gmail.com 


\section{INTRODUCTION}

The school represents an important instrument of socialization. Very important role of school is in psychological development of students, as a meter of fact, in its intellectual and social development. Educational-upbringing contents curricula represent the generally accepted values and norms. The focus is put on promoting the characteristics and abilities which are important for successful social integration, such as: the responsibility, the harmonization of their goals with the goals of others, sensitivity on the needs of the group, pro-social behavior patterns and interactions, cooperation, behavior control, delay of personal needs for satisfaction (Žunic-Pavlović, Pavlović, 2008). During most of the year, children spend much time in school than in any other environment beside than their own home. In school, children need a safe, positive, and comfortable environment so that they can learn undisturbed. Security of the school environment is an important factor that students feel safer, and this ultimately affects to their overall achievement (NCHMP, 2011).

Overall, the schools should be one of the safest places possible for children. However, some schools have problems, such as the violent student behavior, stealing, substance abuse which makes them less safe. These problems lead to the fact that students and teachers feel less safe, which makes more difficulties for students to learn and for teachers to do their work (Pugh, Statham, 2005). There are more research which indicates relationship between the problems at school and behavioral problems. It is known that there are a numbers of risk factors associated with schools functioning of young people in school or acting in the school environment. Risk factors may vary from school to school, depending on the social environment where school is located. School as an important institution may affect on occurrence of behavioral disorders in young people. Research about risk factors in school environment say, from one side, that individual factors are related on the students themselves, and on the other side, on characteristics of the schools as the environment. When schools are not well organized and guided, the children have a less likely for the value of education and the increased probability ofnegative peers' experiences which promote delinquency and opportunities for antisocial behavior (Gottfredson, 2001). Parents, teachers and all those which come into contact with children, standing on the view, at under any circumstances and any time, any child should not have a feeling that their physical safety is in a risk. Prevails view that for ultimate safety of the students, are responsible teachers, parents and the whole community. To make the students worked well in the school environment, their schools must be organized and provide a sense of security. A safe school environment is this one, which is deprived of violent and punishable behavior, and allows to the staff, students and community members to feel connected with the school and provides opportunities to participate in the same important functions -teaching and learning (Adelman, Taylor, 2007). The aim was based on examination of attitudes of students and teachers, to assess the security situation in secondary schools in the Tuzla Canton.

Hypothesis: It is supposed that the attitudes of teachers and students about security situation in secondary schools unfavorable and there is no statistically significant difference in the responses posted on subsamples statements.

\section{WORK METHODS}

\section{The sample of subjects}

The study was conducted on a sample of 160 respondents, who were divided into three subsamples. The first subsample consisted of 50 teachers of secondary schools in Tuzla Canton, the other 55 female students, a third subsample of 55 male students, all grades, selected by random choice method in five secondary schools. 


\section{Comparative way and method of conducting research}

To determine the attitudes about security situation in secondary schools we used the polling, where subjects had to rate the following statements (variables): 1. In the last 5-10 years, our school has improved security situation; 2 . Teaching staff and students are completely assured and safe in our school of any incidents, 3rd In our school often comes to conflict situations; 4 I believe that in our school none of the students and professors do not carry firearms;5th Sometimes I think I get some sort of cold or firearms for protection; 6 . In our school, some students carry a cold weapon (a knife, brass knuckles, dagger); 7th Believe or know that students in our school do not consume alcohol; 8th Believe or know that some students in our school do drugs, 9th I think that parents do not care much for the security situation in the schools; 10th I do not think at all about any kind of danger at school, because I think that everything is in order; 11th In our school shall be continuous education about the prevention and suppression of negative behaviors.

Responses to statements were defined according to the Likert - typescale: completely agree, mostly agree, I cannot decide, mostly disagree, strongly disagree. When the data processing results are summarized in three categories,

so that the answers I completely agree, mostly agree, and answered mostly disagree and strongly disagree represented by one category (agree and disagree). The study was conducted in five secondary schools from five municipalities from the territory Canton, with the direct conduct interviews and help in carrying out the exploration, teachers of classes in which the testing was done.

\section{Methods of data processing}

Results of the research were analyzed by descriptive analysis, frequencies were calculated, percentages and basic statistical parameters and the data presented in tables and graphs. For the test proposed hypotheses used the analysis of variance. Data were analyzed using the statistical program SPSS for Windows 13.0.

\section{RESULTS AND DISCUSSION}

In Table 1 shows the frequency of responses of students and teachers to set assumptions (attitudes) about security situation in secondary schools in Tuzla Canton, arranged according to the three subsamples (I - students, male, II - students, female, and III -teachers). Insight in the results it can be concluded that the results are largely homogeneous, but can be notice with certain differences and individual variables, only in total amount.

The differences are defined, between the students - teachers, on the variables: 3 In our school often comes to conflict situations where the attitudes of the students are divided, and the professors do not agree with the statement, then, on the 8th variable Consider or know that some students in our school do drugs, where the students, as opposed to teachers, they agree with the statement and the variables 9th I think that parents do not care much for the security situation in the schools, where the reverse pleaded. Also, there are distinct differences in responses between female students and teachers in the relation to male students' responses in the variables: 4 Consider that in our school none of the students and professors do not carry firearms, where are the answers the male students divided and the other two samples agree with the statement and 5 Sometimes I think I get some kind of cold or firearms because of protection, where the answers are divided into male student and two other subsamples disagree with the set statement . For all other variables, the answers are arranged so that generally indicates an adverse security situation. 
Table 1. Frequencies and percentages of responses of students and professors about security situation

\begin{tabular}{cccccccccc}
\hline & \multicolumn{3}{c}{ I agree } & \multicolumn{9}{c}{ I can not decide } & \multicolumn{3}{c}{ Disagree } \\
\cline { 2 - 10 } Variables & I & II & III & I & II & III & I & II & III \\
\cline { 2 - 10 } 1. & 16 & 27 & 15 & 19 & 6 & 8 & 20 & 22 & 27 \\
$\mathbf{2}$ & 25 & 21 & 17 & 1 & 10 & 4 & 29 & 24 & 29 \\
$\mathbf{3 .}$ & $\mathbf{2 1}$ & $\mathbf{2 4}$ & $\mathbf{1 2}$ & $\mathbf{1 4}$ & $\mathbf{9}$ & $\mathbf{7}$ & $\mathbf{2 0}$ & $\mathbf{2 2}$ & $\mathbf{3 1}$ \\
$\mathbf{4}$. & $\mathbf{3 0}$ & $\mathbf{2 1}$ & $\mathbf{3 6}$ & $\mathbf{1 1}$ & $\mathbf{1 3}$ & $\mathbf{9}$ & $\mathbf{1 4}$ & $\mathbf{2 1}$ & $\mathbf{5}$ \\
$\mathbf{5 .}$ & $\mathbf{7}$ & $\mathbf{2 4}$ & $\mathbf{9}$ & $\mathbf{6}$ & $\mathbf{5}$ & $\mathbf{5}$ & $\mathbf{4 2}$ & $\mathbf{2 6}$ & $\mathbf{3 6}$ \\
$\mathbf{6 .}$ & 34 & 40 & 26 & 9 & 9 & 20 & 12 & 6 & 4 \\
$\mathbf{7 .}$ & 4 & 6 & 8 & 4 & 11 & 11 & 47 & 38 & 31 \\
$\mathbf{8}$. & $\mathbf{3 3}$ & $\mathbf{2 9}$ & $\mathbf{1 1}$ & $\mathbf{1 1}$ & $\mathbf{1 8}$ & $\mathbf{2 1}$ & $\mathbf{1 3}$ & $\mathbf{8}$ & $\mathbf{1 8}$ \\
$\mathbf{9 .}$ & $\mathbf{1 7}$ & $\mathbf{1 5}$ & $\mathbf{3 1}$ & $\mathbf{5}$ & $\mathbf{1 3}$ & $\mathbf{7}$ & $\mathbf{3 3}$ & $\mathbf{2 7}$ & $\mathbf{1 2}$ \\
$\mathbf{1 0 .}$ & 28 & 22 & $\mathbf{1 2}$ & 5 & 11 & 4 & 22 & 22 & $\mathbf{3 4}$ \\
$\mathbf{1 1}$ & 20 & 18 & $\mathbf{1 0}$ & 12 & 17 & 6 & 23 & 20 & $\mathbf{3 4}$ \\
\hline TOTAL & $\mathbf{2 3 5}$ & $\mathbf{2 4 7}$ & $\mathbf{1 8 7}$ & $\mathbf{9 7}$ & $\mathbf{1 2 2}$ & $\mathbf{1 0 2}$ & $\mathbf{2 7 5}$ & $\mathbf{2 3 6}$ & $\mathbf{2 6 1}$ \\
\hline
\end{tabular}

Table 2 and Figure 1 give a comparative overview of total results expressed in frequencies and percentages, for the three subsamples of subjects. These results indicate differences between groups and the need for conducting further analysis to determine statistical significance of these differences.

Table 2. Frequencies and Percentage of total results

\begin{tabular}{ccccccc}
\hline \multirow{2}{*}{ Subsamples } & \multicolumn{2}{c}{ Agree } & \multicolumn{2}{c}{ I can not decide } & \multicolumn{2}{c}{ Disagree } \\
\cline { 2 - 7 } & f & \% & f & \% & f & $\%$ \\
Students (W) & 235 & 38.71 & 97 & 15.98 & 275 & 45.30 \\
Students (M) & 247 & 40.83 & 122 & 20.17 & 236 & 39.00 \\
Professors & 187 & 34.00 & 102 & 18.55 & 261 & 47.45 \\
\hline
\end{tabular}

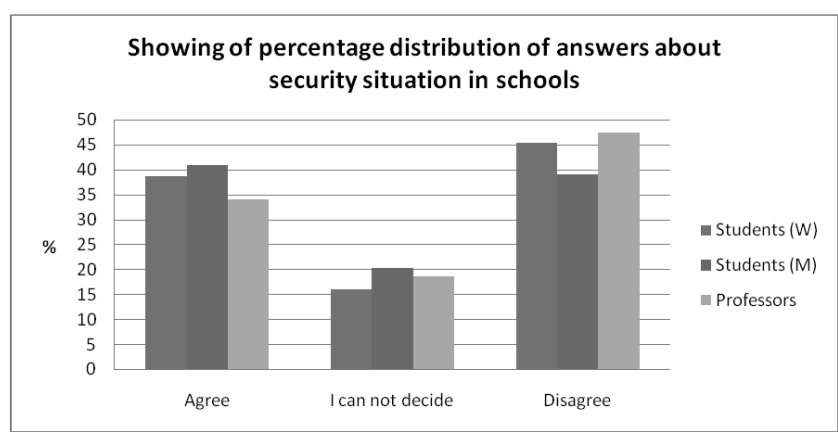

Figure 1. Percentage of answers of subjects

In Table 3 presented the basic statistical parameters of the three subsample of subjects (mean, standard deviation, minimum and maximum result), in the which, according to the assessment of the security situation in secondary schools in $\mathrm{Tu}-$ zla Canton, also shows some differences.
Table 3. Descriptive

\begin{tabular}{cccccc}
\hline Subsample & N & Mean & Std. Deviation & Minimum & Maximum \\
\hline 1 & 50 & 21.48 & 2.410 & 17 & 28 \\
2 & 55 & 21.31 & 3.024 & 15 & 27 \\
3 & 55 & 22.20 & 3.251 & 14 & 30 \\
Total & $\mathbf{1 6 0}$ & $\mathbf{2 1 . 6 7}$ & $\mathbf{2 . 9 3 9}$ & $\mathbf{1 4}$ & $\mathbf{3 0}$ \\
\hline
\end{tabular}

Considering that with descriptive analysis was made a description of answers and that such determined differences are not relevant for assessing the actual values about difference between the subsamples tested by the measurement, the statistical significance of differences was tested by analysis of variance.

Insight in the table 4, we can notice that, by testing the equality of variance, Levene's test of homogeneity, the level of significance higher than 0.05 , - amounts to 0.131 , which indicates that it is not violated assumption about homogeneity of variance.

\section{Table 4. Test of Homogeneity of Variances}

\begin{tabular}{cccc}
\hline Levene Statistic & df1 & df2 & Sig. \\
\hline 2.056 & 2 & 157 & .131 \\
\hline
\end{tabular}

In table 5 are given sum of square deviations of results from their mean values, degrees of of liberty and the mean totals for the analysis of the various subsamples analysis the subsamples, and the $\mathrm{F}$ value and level of significance. Considering that the significance is .245 (greater than .05), it can be concluded that there was no statistically significant difference between mean values responses subsamples about security situation in the secondary schools with the value of $F=1.421$.

Table 6. ANOVA

\begin{tabular}{cccccc}
\hline & Sum of Squares & df & Mean Square & F & Sig. \\
\hline Between Groups & 24.418 & 2 & 12.209 & 1.421 & .245 \\
Within Groups & 1349.025 & 157 & 8.593 & & \\
Total & $\mathbf{1 3 7 3 . 4 4 4}$ & $\mathbf{1 5 9}$ & & & \\
\hline
\end{tabular}

In Table 7 presents the results of subsequent Tukey HSD test to determine statistical significance of differences between pairs of subsamples. 
Considering that there is no statistically significant difference in the analysis between the different subsamples (shown in Table 5, sig. $=.245$ ), it makes no sense to interpret the results of this test and determine exactly where the differences the subsamples.

Table 7. Multiple Comparisons - Tukey HSD test

\begin{tabular}{ccccc|cc}
\hline (I) & (J) & Mean Diff. & Std. & Sig. & \multicolumn{2}{|c}{$\mathbf{9 5 \%}$ Confidence Interval } \\
\cline { 6 - 7 } Subuzo. & Subuzo. & (I-J) & Error & & Lower Bound & Upper Bound \\
\hline 1 & 2 & .171 & .573 & .952 & -1.18 & 1.53 \\
& 3 & -.720 & .573 & .422 & -2.08 & .64 \\
2 & 1 & -.171 & .573 & .952 & -1.53 & 1.18 \\
& 3 & -.891 & .559 & .251 & -2.21 & .43 \\
3 & 1 & .720 & .573 & .422 & -.64 & 2.08 \\
& 2 & .891 & .559 & .251 & -.43 & 2.21 \\
\hline
\end{tabular}

\section{CONCLUSION}

The school, as a educational institutions, should provide optimal conditions in which all Individuals fill safe in such an environment undisturbed by law to perform specified tasks. A large number of different, subjective and objective, positive factors affecting the formation of these conditions. However, in the recent times, schools are increasingly exposed to negative influences, which worsens security situation inside them. The results of this study showed, based on testing of the attitudes of students and teachers of secondary schools in Tuzla Canton, that the security situation in the schools is unfavorable. Also, it was found that, although there are some differences in the expression of attitudes between subsamples (students, professors), these differences are not statistically significant. In relation to obtained results of research, it is necessary to determine the appropriate strategy of action, develop appropriate programs to work with students and implement them promptly in order to secure safer conditions for living and working in the school environment. For the proper functioning of the educational process, it is essential that students and teachers are functioning smoothly, and this means that schools must be well organized and provide a feeling of security.

\section{REFERENCES}

Adelman, H. \& Taylor, L. (2007). Safe and Secure: Guides to Creating Safer Schools. Fostering, School, Family, and Community Involvement, Office of Juvenile Justice and Delinquency Prevention, U.S. Department of Justice.

Gottfredson, D.C. (2001). Crime and delinquency. Children, Youth \& Family. Belsky.

National Center for Mental Health Promotion (NCMHP). (2011). Safe School Environment and Violence Prevention Activities.

Pugh, G. \& Statham, J. (2005). Interventions in Schools in the UK. UC. McAuley (UR), Enhancing the Well-being of children and Families through Effective Interventions: International Evidence for practice. London: Jessica Kingsley Publishers.

Žunić-Pavlović, V. \& Pavlović, M. (2008). Programi prevencije poremećaja ponašanja u školi. UD. Radovanović (Ur.), Poremećaji ponašanja u sistemu obrazovanja. 129139. Beograd, Serbia: Fakultet za specijalnu edukaciju i rehabilitaciju, Centar za izdavačku delatnost. 